doc. dr. sc. Tea Šestanović ${ }^{1}$

prof. dr. sc. Zoran Babić ${ }^{2}$

\title{
PROBABILITY DISTRIBUTION SELECTION USING PROMETHEE GDSS METHOD
}

\author{
Pregledni rad / Review \\ UDK/UDC: 519.2 \\ DOI: 10.51650/ezrvs.15.1-2.5 \\ Primljeno / Received: 14/1/2021 \\ Prihvaćeno / Accepted: 24/2/2021
}

Rising inequalities between countries are widely investigated. Since they involve different aspects, in this paper they are examined through the distribution of countries' growth and development, inclusion and intergenerational equity and sustainability. These aspects involve variables that are not normally distributed so different probability density functions (PDFs) have been proposed, tested and compared through literature. This paper compares different PDFs that are considered successful in describing distribution of the variables involved, as Weibull, gamma, lognormal, normal, loglogistic, Pareto, Burr and exponential. They are usually compared using different goodness-of-fit measures including the log-likelihood, sum of squared errors, sum of absolute errors and chi-square statistics which can sometimes lead to divergent conclusions. This paper adds up to these goodness-of-fit measures and includes the Kolmogorov-Smirnov, Cramer-von Mises and Anderson-Darling statistics, the mean absolute and squared deviation between theoretical and empirical PDF, the mean absolute and squared deviation between theoretical and empirical cumulative distribution function, AIC and BIC as well as the deviation in skewness and kurtosis. Since different distributions can be considered as alternatives and goodness-of-fit measures as conflicting criteria, the problem of finding the appropriate PDF can be viewed as multiple criteria decision making problem which can be solved using PROMETHEE method. However, different preference parameters, lead to different ranking, so the final decision is obtained using PROMETHEE Group Decision Support System (GDSS) method. This paper therefore contributes to the existing literature on inequalities between countries and statistics in general by proposing a new approach for distribution modelling and selection.

Keywords: goodness-of-fit, probability density function, PROMETHEE GDSS method.

\footnotetext{
1 Ekonomski fakultet Sveučilišta u Splitu, e-mail: tea.sestanovic@efst.hr

2 Ekonomski fakultet Sveučilišta u Splitu, e-mail: zoran.babic@efst.hr
} 


\section{Introduction}

Econometric models often assume normality, which in most cases is not satisfied. The consequence is that the $F$ and $t$ statistics of the estimated econometric model are not valid, i.e. only an apparent picture of the direction and the significance of the influence of independent variables on the dependent variable is obtained. Therefore, the appropriate probability distribution selection for the variable of interest is extremely important. The analysis of a probability distribution is a powerful tool to describe several properties of a variable of interest, i.e. much more information is available from the full distribution than from the information given by a simple mean, standard deviation, skewness and kurtosis. There are different parametric, semiparametric and nonparametric methods developed for the estimation of the underlying probability distribution (Cowell and Flachaire, 2015). Although parametric distribution modelling approach requires the a priori selection of the functional form, whereas semiparametric and nonparametric approaches allow the relaxation of the assumptions inherent in parametric models, they require much more data which are not available. Therefore, in this paper eight different parametric distributions are fitted, i.e. Weibull, gamma, lognormal, normal, loglogistic, Pareto, Burr, and exponential, where possible.

The appropriate distribution selection is important for both researchers, as well as practitioners. Although there are already different softwares that enable the automatic distribution selection as SPSS, SAS and Minitab, they usually rely on a single goodness-of-fit criterion and require the selection of either one candidate distribution or more of them. $R$ (Delignette-Muller and Dutang, 2015) and MATLAB enable distribution selection among provided set of possible distributions using different goodness-of-fit measures however they do not yield a single solution. ExpertFit, by Averill Law and Associates (2004), use multiple criteria for selecting the best statistical distribution among a set of candidate statistical distributions and provides a ranking of the best 3 distributions. However, automatical distribution selection is not in the interest of this paper. The usual procedure requires the set hypothesis about the possible distribution, estimation of the parameters and application of Kolmogorov-Smirnov or the chi-square test to test the set hypothesis. It may happen that different decision makers select different distributions if more distributions pass the Kolmogorov-Smirnov or chi-square test (Wang et al., 2004). Stephens (1974) report that the goodness-of-fit tests based on empirical distribution functions are more powerful than the chi-square statistics. Namely, goodness-of-fit measures calculate the distance between empirical and theoretical distribution, and most commonly used, other than Kolmogorov-Smirnov test, are Cramer-von Mises and Anderson-Darling statistics (D'Agostino and Stephens, 1986). Anderson-Darling statistics is interesting to use when the purpose is to emphasise the tails as well as the main body of a distribution, however, it should be used with caution when comparing the goodness-of-fit of various distribution (DelignetteMuller and Dutang, 2015). Moreover, the abovementioned statistics do not take into account the complexity of the model, i.e. the number of parameters, and can lead to a selection of more complex distributions, which in turn can cause the overfitting. The solution is to use the selection criteria that penalize the complexity of the model, like Akaike's (AIC) and Bayesian (BIC) information criteria. The appropriate choice of selection criteria is of great importance for distribution selection. In this paper we add up to abovementioned selection criteria and calculate mean squared deviation of the empirical from the theoretical probability distribution function 
(PDF), mean squared deviation of the empirical from the theoretical cumulative distribution function (CDF), mean absolute deviation of the empirical from the theoretical PDF and mean absolute deviation of the empirical from the theoretical CDF, as well as the distance as a deviation in skewness and kurtosis of the empirical end theoretical distributions. Namely, other than information contained in CDF, the PDF also gives some useful information, as well as their squared and absolute differences. Moreover, the third and fourth central moments of a distribution provide useful information on the shape of the distribution (Wang et al., 2004). Five distribution selection criteria are evaluated in selecting the best fitted distribution among eight widely used distributions in Chen et al. (2017). They indicate that different model selection criteria often give different optimal distributions, where hypothesis tests are more likely to choose complex and information-based criteria simpler models. They conclude that it is better to use the composite criterion.

Since in this paper, there are eight possible distributions that are fitted to a dataset and ten selection criteria, the problem of distribution selection can be viewed as multiple criteria decision making (MCDM) problem. MCDM methods have been developed and widely used in empirical research. However, these methods often rank the alternatives using different approach and while the rankings of the alternatives provided by different methods may be in agreement sometimes, they often lead to divergent results (Baležentis et al., 2012). In order to resolve divergent rankings and disagreements among MCDM methods Kou et al. (2012) proposed an approach based on Spearman's rank correlation coefficient. Poklepović and Babić (2014) combined 5 MCDM methods using hybrid approach based on Spearman's rank correlation coefficient to rank stocks on Croatian capital market, where the weights for all criteria are obtained using AHP. Perić et al. (2019) ranked 21 counties in Croatia using 14 different indicators, and combining 10 MCDM methods using a hybrid MCDM approach based on Spearman's rank correlation coefficient. Other research try to solve the divergent rankings by combining different methods. Kassaee et al. (2013) propose a hybrid MCDM technique to determine the structural relationships and the interrelationships among all the evaluation's dimensions based on the Analytic Network Process (ANP) method determining appropriate weightings to each sub-criterion. Finaly, TOPSIS ranks the alternatives in terms of their overall performances. Chang et al. (2013) address the ranking inconsistency problem and develop a new method selection approach for selecting a fuzzy group MCDM method that produces the most preferred group ranking outcome, based on 2 group averaging methods, 3 aggregation procedures and 3 defuzzification methods in an empirical study on the green bus fuel technology selection problem. Hsu (2014) combined the grey entropy weighting and VIKOR method to rank the Taiwan's 62 listed opto-electronics companies. Babić and Perić (2014) solved the problem of multiproduct vendor selection with volume discounts as the fuzzy multi-objective programming, using an integration of AHP, Weighted sum model and fuzzy multi-objective mixed-integer programming to define the optimum quantities among the selected suppliers. Kabak and Dağdeviren (2014) proposed an integrated approach, which employs ANP and PROMETHEE methods, to assess the sustainability of students' preferences for university selection. Hatami-Marbini and Kangi (2017) presented a group MCDM framework based on 3 versions of fuzzy TOPSIS for selecting undervalued stocks using financial ratios and subjective judgments of experts in financial markets. 
Vuković et al. (2020) compared the hybrid MCDM approach based on 5 different methods with modern portfolio theory (MPT) stock selection. Finally, Ishizaka and Nemery (2011) select the best statistical distribution and show that different preference parameters, given by decision maker in PROMETHEE and GAIA modelling, lead to different ranking, where the final decision is obtained using PROMETHEE Group Decision Support System (GDSS) method. The case study is an engineering problem involving machine tools provided by Wang et al. (2004) who propose the multicriteria evaluation approach for the selection of the best statistical distribution in an engineering problem.

Majority of the research dealing with different decision making problems, in different areas of interest, combine few methods to find the final ranking. Although they sometimes show similar results, they also can produce rather divergent rankings of the alternatives. Therefore, this paper aims to find an alternative approach to find an optimal solution by combining the ranking either from different methods, or from different rankings of the same method, given by different input parameters. Namely, the goal of this paper is to resolve divergent rankings of the alternatives obtained from different PROMETHEE II scenarios, i.e. different decision makers, using an approach based on PROMETHEE Group Decision Support System, which allows to rank the alternatives according to several criteria and decision makers (Macharis et al., 1998). This paper relies on findings of Ishizaka and Nemery (2011) that used the similar methodology with the application to finding the best statistical distribution in an engineering problem.

The application of this paper is distribution fitting of different variables important for the assessment of the countries' economic progress, i.e. GDP per capita, labour productivity, employment, healthy life expectancy, median household income, poverty rate, income gini, wealth gini, adjusted net savings, dependency ratio, public debt as a share of GDP and carbon intensity of GDP (WEF, 2017). Namely, these variables are used to indicate countries' performance, and can indicate on inherent inequality among the countries. They are not normally distributed they show asymmetry and fat-tails, and their distribution should be selected appropriately. Estimated density function for GDP per capita is even bimodal but most of parametric distributions do not fit multimodal distribution (Cowell and Flachaire, 2015) so it is not examined here in that context. Pareto distribution is used to model the income distribution and it is commonly used to model the upper tail of income and wealth distributions. The lognormal distribution is successfully fitted with many different datasets including income, wages, real estate, profits etc. and is often used in empirical research as it is closely related to normal distribution. Gamma and Weibull distributions also show a good fit in empirical studies (Salem and Mount, 1974; Bandourian et al., 2003). The Burr distribution can fit a wide range of empirical data, such as household income, insurance risk, etc., since different values of its parameters cover a broad set of skewness and kurtosis. Moreover, empirical results point that exponential income law universally holds in most countries all over the world, and compared to other distributions, which have two or more fitting parameters, the exponential distribution has only one fitting parameter and produces more parsimonious fit (Tao et al., 2019). Moreover, Chen et al. (2014) prove that the income distribution of urban residents in the period from 2005 to 2010 fits loglogistic distribution. Therefore, in this paper eight different parametric distributions: Weibull, gamma, lognormal, normal, loglogistic, Pareto, Burr, and exponential are fitted where possible to twelve different variables. 
This paper contributes to the existing literature in several ways. Firstly, it emphasises the need for a proper distribution selection, especially in economics but in other sciences as well. Secondly, it points out to different selection criteria that need to be taken into consideration when selecting the appropriate distribution of a random variable. Further, it applies a method for group decision making, i.e. for combining different scenarios, in distribution fitting. Namely, the proposed approach in this paper other than providing different selection criteria it includes subjective judgement in an integrated framework. Finally, it applies the proposed approach for twelve different variables to examine the inequalities between the countries in terms of distribution of countries' growth and development, inclusion and intergenerational equity and sustainability.

The remainder of the paper is organized as follows. Section 2 describes the data and methodology. Section 3 presents empirical findings with discussion of the results. Finally, conclusions and directions for future research are provided in Section 4.

\section{Data and methodology}

\subsection{Data, variables and distribution fitting criteria}

Distribution fitting to a random variable consists in probability distribution selection, parameter estimation and comparison of the selected fitted distributions using various goodness-offit measures. In this paper eight different parametric distributions $f(. \mid \theta)$ with parameter $\theta \in \mathbb{R}^{d}$ where possible (i.e. Weibull, gamma, lognormal, normal, loglogistic, Pareto, Burr, and exponential) are fitted to twelve different continuous random variables (GDP per capita, labour productivity, employment, healthy life expectancy, median household income, poverty rate, income gini, wealth gini, adjusted net savings, dependency ratio, public debt as a share of GDP and carbon intensity of GDP) that are constituents of Inclusive Development Index for year 2018 (WEF, 2018). Detailed explanation of the fitted distributions can be found in Lubrano (2017) and Kleiber and Kotz (2003). Distribution parameters $\theta$ are estimated by maximizing the likelihood function:

$$
L(\theta)=\prod_{i=1}^{n} f\left(x_{i} \mid \theta\right)
$$

where $x_{i}$ are the $n$ observations of variable $X$ and $f(. \mid \theta)$ is the PDF.

To compare different distributions and to find the appropriate one for the particular variable, ten goodness-of-fit measures are employed. Kolmogorov-Smirnov (KS), Cramer-von Mises (CM) and Anderson-Darling (AD) statistics (Stephens, 1986) are calculated as a distance between theoretical $(F)$ and empirical $\left(F_{n}\right)$ CDF, where $x_{i}$ are arranged in an ascending order as:

KS

$$
\max \left(D^{+}, D^{-}\right), \text {where } D^{+}=\max _{i=1, \ldots, n}\left(\frac{i}{n}-F_{i}\right) \text { and } D^{-}=\max _{i=1, \ldots, n}\left(F_{i}-\frac{i-1}{n}\right)
$$

$\mathrm{CM}$

$$
\frac{1}{12 n}+\sum_{i=1}^{n}\left(F_{i}-\frac{2 i-1}{2 n}\right)^{2}
$$

$A D$

$$
-n-\frac{1}{n} \sum_{i=1}^{n}(2 i-1) \log \left(F_{i}\left(1-F_{n+1-i}\right)\right)
$$

where $F_{i} \equiv F\left(x_{i}\right)$ for simplicity. 
Akaike's (AIC) and Bayesian Information Criteria (BIC) are calculated as:

$$
\begin{gathered}
A I C=-2 \cdot \text { loglikelihood }+2 \cdot k \\
B I C=-2 \cdot \text { loglikelihood }+2 \cdot \ln (n)
\end{gathered}
$$

where $k$ is the number of estimated parameters. Mean squared deviation of the empirical from the theoretical PDF $\left(M S E_{p}\right)$, mean squared deviation of the empirical from the theoretical CDF $\left(M S E_{c}\right)$, mean absolute deviation of the empirical from the theoretical PDF $\left(M A E_{p}\right)$ and mean absolute deviation of the empirical from the theoretical $\operatorname{CDF}\left(M A E_{C}\right)$ are calculated as:

$$
\begin{aligned}
\operatorname{MSE}_{P} & =\frac{1}{n} \sum_{i=1}^{n}\left(f\left(x_{i}\right)-f_{n}\left(x_{i}\right)\right)^{2} \\
M S E_{C} & =\frac{1}{n} \sum_{i=1}^{n}\left(F\left(x_{i}\right)-F_{n}\left(x_{i}\right)\right)^{2} \\
M A E_{P} & =\frac{1}{n} \sum_{i=1}^{n}\left|f\left(x_{i}\right)-f_{n}\left(x_{i}\right)\right| \\
M^{\prime} E_{C} & =\frac{1}{n} \sum_{i=1}^{n}\left|F\left(x_{i}\right)-F_{n}\left(x_{i}\right)\right|
\end{aligned}
$$

Finally, the distance as a deviation in skewness and kurtosis (Wang et al, 2004) is:

$$
D=\sqrt{\left(\alpha_{3}-\hat{\alpha}_{3}\right)^{2}\left(\alpha_{4}-\hat{\alpha}_{4}\right)^{2}}
$$

where $a_{3^{\prime}} a_{4}$ and $\hat{a}_{3^{\prime}} \hat{a}_{4}$ are coefficients of skewness and kurtosis of the empirical end theoretical distributions respectively. The lower the values of all goodness-of-fit measures the better the sample fits the selected distribution.

Since for each variable there are eight different distributions (alternatives) that are fitted, where possible, and evaluated using ten goodness-of-fit measures (criteria), the problem of probability distribution selection becomes a multi criteria decision making problem which is solved using PROMETHEE method.

\subsection{PROMETHEE and GDSS methods}

PROMETHEE (Preference Ranking Organization METHod for Enrichment Evaluation) compares and ranks alternatives which are simultaneously evaluated on at least two quantitative and qualitative criteria (Brans and Marechal, 2005). It is commonly used in MCDM problems. Suppose the following multicriteria problem:

$$
\operatorname{Max}\left\{f_{1}(a), f_{2}(a), \ldots ., f_{n}(a) \mid a \in A\right\}
$$

where $A$ is a finite set of possible alternatives, i.e. $A=\left\{A_{1}, A_{2}, \ldots A_{\mathrm{m}}\right\}$, and $f_{j}$ are $n$ criteria which have to be maximized. When two alternatives $a$ and $b\left(A_{k}\right.$ and $\left.A_{1}\right)$ are compared with respect to particular criterion the result of the comparison has to be expressed in terms of preferences. A preference function defined as $P: A \times A \rightarrow[0,1]$, gives the intensity of preference of the alternative $a$ over the alternative $b$. One preference function out of six types is selected for each criterion depending on the intensity and the course of preferences. Moreover, for each criterion the relative importance (weight) $w_{j}$ is determined. After specifying preference 
function $P_{j}$ and weight $w_{j}$ for each criterion $f_{j^{\prime}}$ the preference index $\Pi$ is defined as the weighted average of the preference functions $P$ :

$$
\Pi(a, b)=\frac{\sum_{j=1}^{n^{j}} w_{j} P_{j}(a, b)}{\sum_{j=1}^{n} w_{j}}
$$

Preference index $\Pi(a, b)$ represents the intensity of preference of the decision maker of alternative $a$ over alternative $b$, when considering simultaneously all the criteria. For each alternative positive $\Phi^{+}(a)$ and negative flows $\Phi^{-}(a)$ are defined:

$$
\Phi^{+}(a)=\frac{1}{m-1} \sum_{x \in A} \Pi(a, x), \Phi^{-}(a)=\frac{1}{m-1} \sum_{x \in A} \Pi(x, a)
$$

Positive flow expresses how an alternative $a$ is outranking all the others. It is its power, i.e. the higher $\Phi^{+}(a)$, the better the alternative. Negative flow provides a measure of the outranked character of $a$. It is its weakness, i.e. the lower the $\Phi^{-}(a)$, the better the alternative. That is PROMETHEE I partial relation. A total preorder (complete ranking without incomparabilities) or PROMETHEE II complete relation is further defined by considering for each alternative $a \in A$ the net outranking flow as the balance between the "power" and the "weakness" for each alternative:

$$
\Phi(a)=\Phi^{+}(a)-\Phi^{-}(a) .
$$

The higher the net flow $\Phi(a)$ the better the alternative.

Since different weights of criteria and different preference function parameters defined by the decision maker lead to different rankings, a group decision can be reached using the PROMETHEE GDSS model. It allows to rank the alternatives according to several criteria and decision makers (Macharis et al., 1998). Namely, in PROMETHEE GDSS approach each ranking given by the net flows is considered as a criterion in a new global model. This new global model collects for each decision maker, or for each scenario containing different rankings obtained by alternating weights of criteria and preference functions, the net flow vector in a global decision matrix and applies PROMETHEE II, where additionally each global criterion can have the same or a different weight.

\subsection{Scenarios}

Different decision makers can choose different combination of preference functions and criteria weights, yielding with divergent alternatives' ranking. In this paper, three different scenarios are presented. The first scenario has the same weight for all criteria and uses usual criterion. The second scenario has the same weight for all criteria and uses Gaussian criterion with the parameter $s$ corresponding to a standard deviation of each criterion. In the third scenario decision maker defines the weights of criteria (obtained by eigenvector method Saaty (2001)) and the set of generalized criteria. The weights of criteria for the third scenario are given in Table 2 and the set of generalized criteria with defined parameters ( $q, p$ and $s$ ) in Tables 3-5. Finally, the PROMETHEE GDSS is applied to tree scenarios to get the final ranking of the alternatives, where the net flows of each decision maker have the same weight, 
assuming that all the decision makers are experts in this field, with the set of generalized criteria and defined parameters ( $q, p$ and s) given in Tables 6-8.

\section{Empirical results}

Descriptive statistics with sample size, minimum, maximum, median, mean $(\mu)$, standard deviation $(\sigma)$, skewness $\left(a_{3}\right)$ and kurtosis $\left(a_{4}\right)$ for twelve variables (GDP per capita, labour productivity, employment, healthy life expectancy, median household income, poverty rate, income gini, wealth gini, adjusted net savings, dependency ratio, public debt/GDP and carbon intensity/GDP) that are constituents of Inclusive Development Index for 2018 (WEF, 2018) are given in Table $1^{3}$.

Table 1 Descriptive statistics

\begin{tabular}{|l|c|c|c|c|c|c|c|c|}
\hline & $\mathbf{N}$ & $\mathbf{M i n}$ & $\mathbf{m a x}$ & median & $\boldsymbol{\mu}$ & $\boldsymbol{\sigma}$ & $\mathbf{a}_{\mathbf{3}}$ & $\mathbf{a}_{\mathbf{4}}$ \\
\hline GDP per capita & 99 & 218 & 111001 & 6491.5 & 16562.3 & 21842.7 & 1.96 & 7.00 \\
\hline Median daily income & 99 & 1.10 & 63.80 & 9.15 & 16.33 & 16.10 & 1.25 & 3.49 \\
\hline Public debt & 94 & 9.50 & 239.20 & 52.05 & 58.78 & 34.51 & 2.24 & 11.29 \\
\hline Carbon intensity & 99 & 3.20 & 1104.6 & 54.50 & 104.04 & 154.45 & 4.47 & 27.17 \\
\hline Poverty rate & 99 & 0.30 & 91.10 & 11.70 & 23.29 & 26.81 & 1.36 & 3.46 \\
\hline Employment rate & 99 & 34.80 & 84.60 & 58.55 & 58.14 & 11.20 & 0.28 & 2.83 \\
\hline Income gini & 99 & 24.40 & 57.70 & 37.10 & 37.15 & 7.44 & 0.32 & 2.61 \\
\hline Wealth gini & 99 & 44.80 & 92.60 & 69.90 & 69.41 & 11.49 & -0.22 & 2.45 \\
\hline Life expectancy & 99 & 44.40 & 74.90 & 66.45 & 64.42 & 7.27 & -0.95 & 3.12 \\
\hline Labour productivity & 99 & 1451 & 206734 & 35338 & 43846.5 & 36825.7 & 1.34 & 5.90 \\
\hline Dependency ratio & 99 & 35.20 & 101.50 & 53.00 & 57.91 & 15.28 & 1.30 & 4.02 \\
\hline Adjusted net savings & 94 & -15.30 & 40.40 & 7.80 & 8.61 & 10.29 & 0.17 & 3.27 \\
\hline
\end{tabular}

Source: authors' calculations in R Studio

\footnotetext{
${ }^{3}$ Number of observations depends on the data availability. WEF (2018) has data for 107 countries. Since Cambodia, Chad, Costa Rica, Dominican Republic, Guatemala, Honduras, Iran, Lesotho, Kenya, Mongolia, Morocco, New Zealand, Singapore have missing data for certain variables, they are eliminated from further calculations.
} 
Figure 1 Histogram and theoretical PDFs (upper left), empirical and theoretical CDFs (lower left), Q-Q plot (upper right) and P-P plot (lower right) for GDP per capita
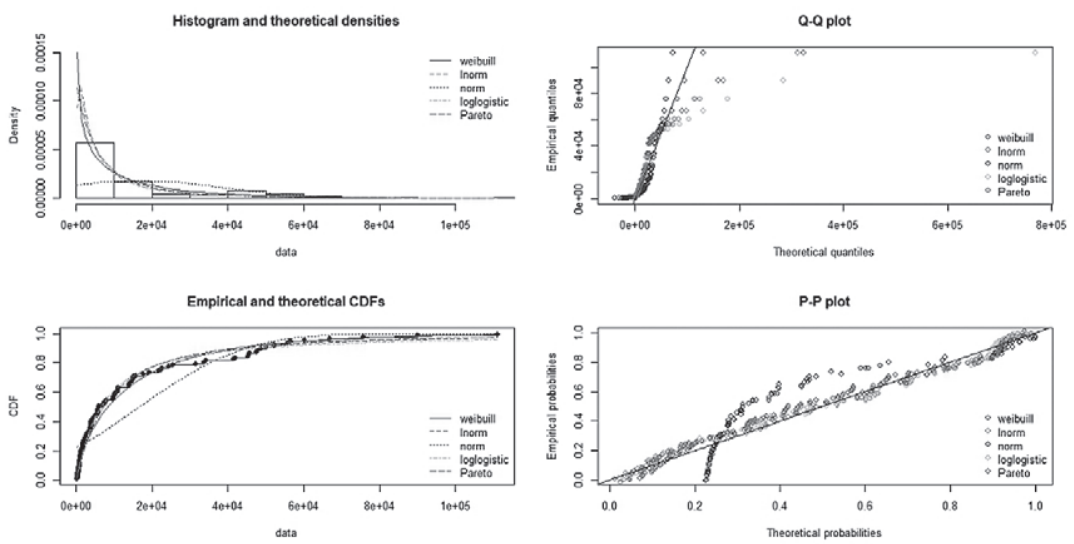

Source: authors' calculations in R Studio

Variables exhibit both positive and negative skewness with mostly leptokurtic but also platykurtic distributions. Large differences between countries can be observed also from Figures 1-3. There are inherent inequalities among the countries. GDP per capita has the coefficient of variation of $131,9 \%$ indicating large dispersion. The same can be concluded for all variables. The aim of this paper is to find the appropriate distribution for each variable among eight parametric distributions: Weibull (W), gamma (G), lognormal (LN), normal (N), loglogistic (LL), Pareto (P), Burr (B) and exponential (E).

Using ten criteria, for GDP per capita, median daily income and public debt the results are inconclusive, i.e. some criteria favour one distribution over the others. The results for these variables are given in Tables 3-5 with the best alternative according to each criterion bolded. Density function of the fitted distributions along with histogram of the empirical distribution (upper left panel), empirical and fitted CDFs (lower left panel), Q-Q plot (upper right panel) representing the empirical against the theoretical quantiles and P-P plot (lower right panel) representing the empirical against fitted distribution function evaluated at each data point, are given in Figures 1 to 3. Density and CDF plots may be considered as the basic classical goodness-of-fit plots. The Q-Q plot emphasizes the lack-of-fit at the distribution tails while the P-P plot emphasizes the lack-of-fit at the distribution centre (Delignette-Muller and Dutang, 2015). For GDP per capita (Figure 1) only the normal distribution stands out in all the plots as the distribution that does not fit the data at all. Moreover, at the distribution tails the Weibull distribution for GDP per capita seems to have the best fit. For median daily income (Figure 2) also normal distribution stands out in all the plots as the distribution that does not fit well the data, whereas Burr and lognormal have the best fit at the tails of the distribution. For public debt (Figure 3) Pareto and exponential distributions do not fit the data well. For other variables the appropriate distribution is either uniquely selected using all criteria or the criteria show conflicting results in only 2 or 3 cases. For carbon intensity in 6 out of 10 criteria and for employment rate in 7 out of 10 criteria the Burr distribution is the optimal one. For poverty rate the distribution is either Weibull, loglogistic or exponential; net income gini follows Gamma distribution; 
wealth gini, life expectancy and labour productivity Weibull; dependency ratio either lognormal or loglogistic in most cases; while adjusted net savings follow normal distribution ${ }^{4}$.

Figure 2 Histogram and theoretical PDFs (upper left), empirical and theoretical CDFs (lower left), $Q-Q$ plot (upper right) and P-P plot (lower right) for median daily income
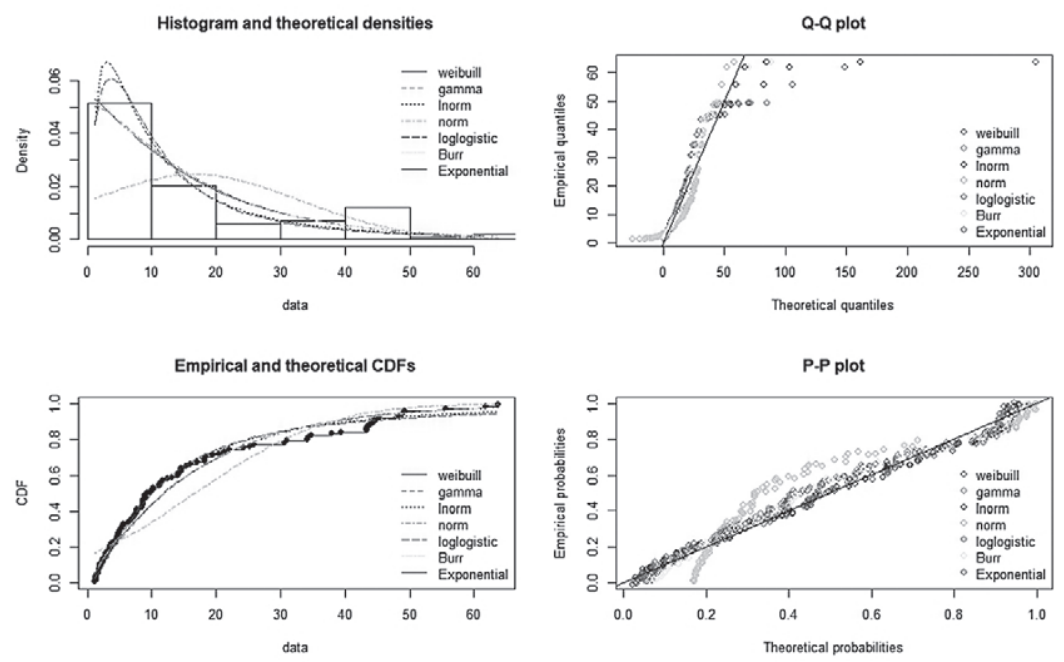

Source: authors' calculations in R Studio

Figure 3 Histogram and theoretical PDFs (upper left), empirical and theoretical CDFs (lower left), $Q-Q$ plot (upper right) and P-P plot (lower right) for public debt
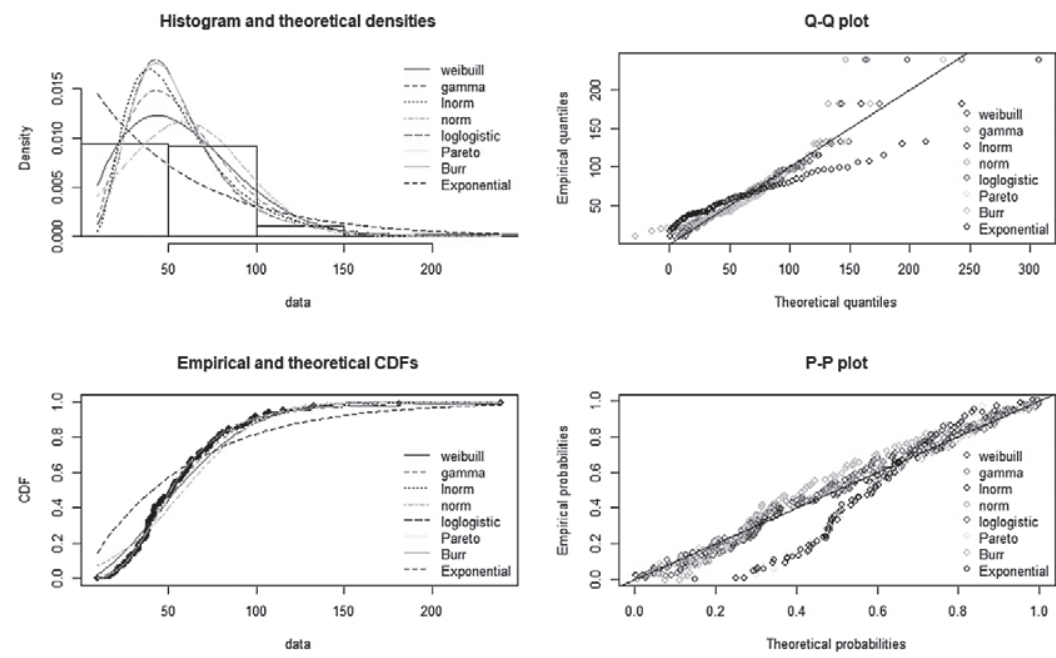

Source: authors' calculations in R Studio

\footnotetext{
${ }^{4}$ The results for other variables are not presented due to the lack of space and are available from the authors upon request.
} 
For three variables that show the conflict among the criteria in distribution selection, i.e. GDP per capita, median daily income and public debt, there is a motive to further use PROMETHEE method. The weights of criteria are set to one for each criterion in Scenario 1 and 2, while for Scenario 3 they are obtained using the eigenvector method in Expert choice. Scenario 1 uses the Usual preference function type, while Scenario 2 uses the Gaussian preference function type with the parameter $s$ corresponding to a standard deviation of each criterion ${ }^{5}$. The preference function types, along with thresholds ( $q, p$ and $s$ ) and criteria weights for Scenario 3 are given in Tables 2-4 along with the decision matrices.

Table 2 Decision matrix with preference function types and thresholds in Scenario 3 for GDP per capita

\begin{tabular}{|l|c|c|c|c|c|c|c|c|c|c|}
\hline & KS & CM & AD & AIC & BIC & MSEp & MSEc & MAEp & MAEc & D \\
\hline W & 0.082 & 0.14 & 1.01 & 2088.6 & 2093.7 & $1.33 E-10$ & $\mathbf{1 . 6 4 E - 8}$ & $3.48 E-6$ & $\mathbf{9 . 3 9 E}-\mathbf{5}$ & 152.4 \\
\hline LN & 0.066 & $\mathbf{0 . 0 8}$ & $\mathbf{0 . 6 2}$ & $\mathbf{2 0 8 4 . 0}$ & $\mathbf{2 0 8 9 . 1}$ & $1.19 \mathrm{E}-10$ & $2.04 \mathrm{E}-8$ & $3.72 \mathrm{E}-6$ & $1.18 \mathrm{E}-4$ & 36.7 \\
\hline N & 0.242 & 1.80 & 9.41 & 2239.5 & 2244.6 & $\mathbf{6 . 1 1 E}-11$ & $1.49 \mathrm{E}-7$ & $4.49 \mathrm{E}-6$ & $3.00 \mathrm{E}-4$ & $\mathbf{6 . 7}$ \\
\hline LL & $\mathbf{0 . 0 6 2}$ & 0.09 & 0.74 & 2090.8 & 2095.9 & $1.65 \mathrm{E}-10$ & $9.11 \mathrm{E}-6$ & $7.05 \mathrm{E}-6$ & $2.80 \mathrm{E}-3$ & 10244.6 \\
\hline P & 0.075 & 0.11 & 0.86 & 2089.0 & 2094.2 & $9.56 \mathrm{E}-11$ & $2.00 \mathrm{E}-8$ & $\mathbf{3 . 4 7 E}-\mathbf{6}$ & $1.02 \mathrm{E}-4$ & 22.0 \\
\hline S3 & $\mathrm{V}$ & $\mathrm{V}$ & $\mathrm{V}$ & $\mathrm{VI}$ & $\mathrm{VI}$ & $\mathrm{IV}$ & $\mathrm{III}$ & IV & III & I \\
\hline w $_{\mathrm{j}}$ & 78.45 & 55.77 & 210.37 & 109.37 & 290.62 & 18.82 & 18.82 & 38.75 & 27.20 & 151.78 \\
\hline $\mathrm{q}$ & 0.01 & 0.015 & 0.1 & & & 0.4 & & 0.4 & & \\
\hline p & 0.1 & 0.5 & 0.3 & & & 1 & 2 & 1 & 2 & \\
\hline s & & & & 67.75 & 67.74 & & & & & \\
\hline
\end{tabular}

Source: authors' calculations in R Studio

Table 3 Decision matrix with preference function types and thresholds in Scenario 3 for median daily income

\begin{tabular}{|l|c|c|c|c|c|c|c|c|c|c|}
\hline & KS & CM & AD & AIC & BIC & MSEp & MSEc & MAEp & MAEc & D \\
\hline W & 0.087 & 0.176 & 1.232 & 747.3 & 752.4 & $3.94 \mathrm{E}-5$ & 0.0306 & 0.0038 & 0.1357 & 0.0966 \\
\hline G & 0.093 & 0.204 & 1.349 & 746.9 & 752.0 & $\mathbf{3 . 5 9 E}-\mathbf{5}$ & 0.0348 & 0.0038 & 0.1436 & $\mathbf{0 . 0 2 1 5}$ \\
\hline LN & 0.072 & $\mathbf{0 . 0 6 8}$ & $\mathbf{0 . 6 6 7}$ & $\mathbf{7 4 2 . 8}$ & $\mathbf{7 4 8 . 0}$ & $5.90 \mathrm{E}-5$ & 0.0490 & 0.0041 & 0.1923 & 1.8012 \\
\hline N & 0.196 & 1.219 & 6.810 & 825.8 & 830.9 & $7.48 \mathrm{E}-5$ & 0.1880 & 0.0063 & 0.3020 & 2.3020 \\
\hline LL & $\mathbf{0 . 0 6 9}$ & 0.074 & 0.733 & 749.5 & 754.6 & $1.60 \mathrm{E}-2$ & 1.6544 & 0.0177 & 1.0425 & 8720.7 \\
\hline B & 0.078 & 0.139 & 1.054 & 749.1 & 756.9 & $3.76 \mathrm{E}-5$ & 0.0326 & $\mathbf{0 . 0 0 3 7}$ & 0.1401 & 0.1007 \\
\hline E & 0.076 & 0.140 & 1.091 & 745.4 & 748.0 & $4.42 \mathrm{E}-5$ & $\mathbf{0 . 0 2 6 5}$ & 0.0039 & $\mathbf{0 . 1 2 6 2}$ & 0.3290 \\
\hline S3 & $\mathrm{V}$ & $\mathrm{V}$ & $\mathrm{V}$ & $\mathrm{VI}$ & $\mathrm{VI}$ & $\mathrm{IV}$ & $\mathrm{III}$ & $\mathrm{IV}$ & III & I \\
\hline w & 78.45 & 55.77 & 210.37 & 109.37 & 290.62 & 18.82 & 18.82 & 38.75 & 27.20 & 151.78 \\
\hline $\mathrm{q}$ & 0.01 & 0.01 & 0.1 & & & 1 & & 0.02 & & \\
\hline p & 0.1 & 0.1 & 0.3 & & & 2 & 0.5 & 0.3 & 0.5 & \\
\hline s & & & & 29.93 & 30.00 & & & & & \\
\hline
\end{tabular}

Source: authors' calculations in R Studio

\footnotetext{
${ }^{5}$ It is not given since it can be calculated from the decision matrix and is available from the authors upon request.
} 
Net flows and rankings of distributions for different scenarios and finally for GDSS PROMETHEE method for GDP per capita, median daily income and public debt are given in Tables 5-7 respectively. Since different weights of criteria and preference function parameters defined by the decision maker lead to different rankings of the appropriate distributions for each variable, a group decision can be reached using the PROMETHEE GDSS model. The preference function types with thresholds ( $q, p$ and $s$ ) for PROMETHEE GDSS method are also given in Tables 5-7 along with the final rankings in the last column.

Table 4 Decision matrix with preference function types and thresholds in Scenario 3 for public debt

\begin{tabular}{|l|c|c|c|c|c|c|c|c|c|c|}
\hline & KS & CM & AD & AIC & BIC & MSEp & MSEc & MAEp & MAEc & D \\
\hline W & 0.080 & 0.212 & 1.509 & 907.9 & 913.0 & $1.25 E-6$ & 0.0013 & 0.0007 & 0.0269 & 0.4589 \\
\hline G & 0.079 & 0.074 & 0.478 & 895.4 & 900.5 & $\mathbf{1 . 5 1 E - 7}$ & 0.0003 & $\mathbf{0 . 0 0 0 3}$ & 0.0155 & $\mathbf{0 . 0 3 6 1}$ \\
\hline LN & $\mathbf{0 . 0 5 4}$ & $\mathbf{0 . 0 2 8}$ & 0.195 & 891.0 & 896.0 & $4.95 \mathrm{E}-7$ & $\mathbf{0 . 0 0 0 3}$ & 0.0005 & $\mathbf{0 . 0 1 2 5}$ & 0.0642 \\
\hline N & 0.126 & 0.484 & 3.016 & 935.5 & 940.6 & $3.34 \mathrm{E}-6$ & 0.0048 & 0.0012 & 0.0446 & 0.5581 \\
\hline LL & 0.069 & 0.036 & 0.197 & $\mathbf{8 9 0 . 3}$ & $\mathbf{8 9 5 . 4}$ & 4.01 & 1799.2 & 0.0920 & 40.9 & 10682.8 \\
\hline P & 0.276 & 2.110 & 11.078 & 957.9 & 963.0 & $1.61 \mathrm{E}-5$ & 0.0234 & 0.0023 & 0.1050 & 0.1582 \\
\hline B & 0.071 & 0.036 & $\mathbf{0 . 1 9 4}$ & 892.2 & 899.9 & $5.45 \mathrm{E}-7$ & 0.0004 & 0.0005 & 0.0142 & 0.1573 \\
\hline E & 0.276 & 2.108 & 11.070 & 955.9 & 958.4 & $1.61 \mathrm{E}-5$ & 0.0234 & 0.0023 & 0.1051 & 0.1574 \\
\hline S3 & $\mathrm{V}$ & $\mathrm{V}$ & $\mathrm{V}$ & $\mathrm{VI}$ & $\mathrm{VI}$ & $\mathrm{IV}$ & $\mathrm{III}$ & $\mathrm{IV}$ & $\mathrm{III}$ & I \\
\hline $\mathrm{w}_{j}$ & 78.45 & 55.77 & 210.37 & 109.37 & 290.62 & 18.82 & 18.82 & 38.75 & 27.20 & 151.78 \\
\hline q & 0.01 & 0.01 & 0.1 & & & 1 & & 0.5 & & \\
\hline p & 0.1 & 0.1 & 0.3 & & & 4 & 0.5 & 1 & 3 & \\
\hline S & & & & 29.44 & 28.67 & & & & & \\
\hline
\end{tabular}

Source: authors' calculations in R Studio

Table 5 Net flows and rankings of distributions for different scenarios and GDSS PROMETHEE method for GDP per capita

\begin{tabular}{|c|c|c|c|c|c|c|c|c|}
\hline & \multicolumn{2}{|c|}{ Scenario 1} & \multicolumn{2}{|c|}{ Scenario 2} & \multicolumn{2}{|c|}{ Scenario 3} & & \\
\hline Type & \multicolumn{2}{|c|}{ III } & \multicolumn{2}{|c|}{ V } & \multicolumn{2}{|c|}{ III } & & \\
\hline$q$ & & & \multicolumn{2}{|c|}{0.1} & & & & \\
\hline$p$ & \multicolumn{2}{|c|}{0.9} & 0.5 & & \multicolumn{2}{|c|}{0.8} & & \\
\hline $\mathrm{s}$ & & & & & & & GD & \\
\hline Dist. & $\Phi$ & rank & $\Phi$ & rank & $\Phi$ & rank & $\Phi$ & rank \\
\hline W & 0.1 & 3 & 0.1856 & 3 & 0.028 & 3 & 0.2269 & 3 \\
\hline LN & 0.45 & 1 & 0.2051 & 2 & 0.3122 & 1 & 0.5272 & 1 \\
\hline $\mathrm{N}$ & -0.45 & 5 & -0.3157 & 5 & -0.5872 & 5 & -0.7481 & 5 \\
\hline LL & -0.4 & 4 & -0.3114 & 4 & -0.0207 & 4 & -0.4454 & 4 \\
\hline$P$ & 0.3 & 2 & 0.2364 & 1 & 0.2678 & 2 & 0.4393 & 2 \\
\hline
\end{tabular}

Source: authors' calculations in Decision Lab 
Table 6 Net flows and rankings of distributions for different scenarios and GDSS PROMETHEE method for median daily income

\begin{tabular}{|c|c|c|c|c|c|c|c|c|}
\hline & \multicolumn{2}{|c|}{ Scenario 1} & \multicolumn{2}{|c|}{ Scenario 2} & \multicolumn{2}{|c|}{ Scenario 3} & & \\
\hline Type & \multicolumn{2}{|c|}{ III } & \multicolumn{2}{|c|}{ V } & \multicolumn{2}{|c|}{ III } & & \\
\hline$q$ & & & \multicolumn{2}{|c|}{0.1} & & & & \\
\hline$p$ & \multicolumn{2}{|c|}{1.1} & 0.5 & & \multicolumn{2}{|c|}{1.1} & & \\
\hline $\mathrm{s}$ & & & & & & & GD & \\
\hline Dist. & $\Phi$ & rank & $\Phi$ & rank & $\Phi$ & rank & $\Phi$ & rank \\
\hline W & 0.1667 & 4 & 0.1603 & 4 & 0.1074 & 4 & 0.208 & 4 \\
\hline G & 0.1333 & 5 & 0.1548 & 5 & 0.0518 & 6 & 0.1766 & 5 \\
\hline LN & 0.2833 & 2 & 0.1731 & 1 & 0.259 & 1 & 0.3009 & 2 \\
\hline $\mathrm{N}$ & -0.8333 & 7 & -0.4247 & 7 & -0.8629 & 7 & -0.8696 & 7 \\
\hline LL & -0.3667 & 6 & -0.3965 & 6 & 0.0768 & 5 & -0.3803 & 6 \\
\hline B & 0.2333 & 3 & 0.1637 & 3 & 0.1924 & 2 & 0.2616 & 3 \\
\hline$E$ & 0.3833 & 1 & 0.1693 & 2 & 0.1754 & 3 & 0.3028 & 1 \\
\hline
\end{tabular}

Source: authors' calculations in Decision Lab

Table 7 Net flows and rankings of distributions for different scenarios and GDSS PROMETHEE method for public debt

\begin{tabular}{|c|c|c|c|c|c|c|c|c|}
\hline & \multicolumn{2}{|c|}{ Scenario 1} & \multicolumn{2}{|c|}{ Scenario 2} & \multicolumn{2}{|c|}{ Scenario 3} & & \\
\hline Type & \multicolumn{2}{|c|}{ III } & \multicolumn{2}{|c|}{$\mathrm{V}$} & \multicolumn{2}{|c|}{ III } & & \\
\hline$q$ & & & \multicolumn{2}{|c|}{0.1} & & & & \\
\hline$p$ & \multicolumn{2}{|c|}{1.1} & 0.5 & & \multicolumn{2}{|c|}{1.1} & & \\
\hline $\mathrm{s}$ & & & & & & & GD & \\
\hline Dist. & $\Phi$ & rank & $\Phi$ & rank & $\Phi$ & rank & $\Phi$ & rank \\
\hline W & -0.0571 & 4 & 0.1828 & 4 & 0.0296 & 5 & 0.1325 & 4 \\
\hline G & 0.4857 & 3 & 0.2225 & 3 & 0.3761 & 3 & 0.4463 & 3 \\
\hline LN & 0.8286 & 1 & 0.237 & 1 & 0.5141 & 1 & 0.5837 & 1 \\
\hline $\mathrm{N}$ & -0.3429 & 6 & 0.0338 & 5 & -0.3544 & 6 & -0.1943 & 5 \\
\hline LL & -0.1286 & 5 & -0.3266 & 8 & 0.1112 & 4 & -0.2275 & 6 \\
\hline$P$ & -0.7429 & 8 & -0.2923 & 7 & -0.577 & 8 & -0.6381 & 8 \\
\hline$B$ & 0.5286 & 2 & 0.2289 & 2 & 0.4623 & 2 & 0.4899 & 2 \\
\hline$E$ & -0.5714 & 7 & -0.286 & 6 & -0.562 & 7 & -0.5925 & 7 \\
\hline
\end{tabular}

Source: authors' calculations in Decision Lab

For GDP per capita the best distribution is either lognormal or Pareto according to Scenarios 1-3, while the worst distribution is always normal. Using GDSS PROMETHEE method lognormal distribution is selected as the most appropriate for GDP per capita. For median daily income the best distribution is either lognormal or exponential according to Scenarios 1-3, while the worst distribution is always normal. Using GDSS PROMETHEE method the exponential distribution is selected as the most appropriate for median daily income. For public debt, the best distribution is always lognormal according to all Scenarios, while the 
worst distribution is either Pareto or loglogistic. Using GDSS PROMETHEE method the lognormal distribution is selected as the most appropriate for public debt.

\section{Conclusion}

In this paper the aim was to find the appropriate statistical distribution for different variables that are the indicators of inequalities between the countries, i.e. the indicators of countries' growth and development, inclusion and intergenerational equity and sustainability. By examining eight different distributions for twelve variables using ten selection criteria, the consensus about the best statistical distribution could not be reached for three variables: GDP per capita, median daily income and public debt. For other variables the appropriate distribution is either uniquely selected using all criteria or the criteria show conflicting results in only two or three cases. The Burr distribution is the optimal for carbon intensity and employment rate. Net income gini follows Gamma distribution, whereas wealth gini, life expectancy and labour productivity follow the Weibull distribution. Adjusted net savings follow normal distribution, while dependency ratio has in most cases loglogistic distribution. For poverty rate the distribution is mostly Weibull. Only variables for which the consensus about best statistical distribution could not be met are further investigated. Namely, since eight possible parametric distributions are examined using ten criteria, the selection of the appropriate distribution can be seen as MCDM problem which can be solved using PROMETHEE II method. In this paper three scenarios are proposed, representing three different decision makers. Since different decision makers choose different combinations of preference functions and weights, yielding each time with different ranking of the alternatives, the PROMETHEE GDSS method is applied to get the final group ranking of the alternatives. The results of PROMETHEE GDSS method show that for GDP per capita the best distribution is lognormal, while the worst distribution is normal. For median daily income the best distribution is exponential, while the worst distribution is normal. Finally, for public debt, the best distribution is lognormal, while the worst distribution is Pareto. The results are in line with previous research that point out to the necessity to correctly apply the appropriate distribution in econometric modelling since these variables, that are most commonly used as indicators of countries' growth and development, inclusion and intergenerational equity and sustainability, do not follow the normal distribution in most cases. However, a clear consensus can not be reached for all the variables involved since the Weibull distribution is selected 4 times as the best distribution, lognormal and Burr distributions are selected two times whereas gamma, normal, loglogistic and exponential are each selected one time as the most appropriate distribution. Only Pareto distribution is never the best one for neither of the variables. Since the distribution of the same variable in another observed year can be changed, these results are valid but that they are not worth in general. Further research should be conducted in different periods to investigate whether the same conclusions can be reached regarding the distribution selection. Therefore, both researchers and practitioners should be careful when selecting the appropriate distribution. They should use the proposed criteria and PROMETHEE GDSS methodology to get the final consensus about the best distribution. 


\section{REFERENCES}

1. Averill M. Law and Associates, Inc. (2004), ExpertFit Distribution Fitting Software. P.O. Box 40996, Tucson, AZ85717, USA, http://www.averill-law.com/distribution-fitting/[15.02.2021]

2. Babić, Z., Perić, T. (2014). Multiproduct Vendor Selection with Volume Discounts as the Fuzzy Multi-Objective Programming Problem. International Journal of Production Research, 52(14), pp. 4315-4331.

3. Baležentis, A., Baležentis, T., Misiunas, A. (2012). An integrated assessment of Lithuanian economic sectors based on financial ratios and fuzzy MCDM methods. Technological and Economic Development of Economy, 18(1), pp. 34-53

4. Bandourian, R., McDonald, J. B., Turley, R. S. (2003). A comparison of parametric models of income distribution across countries and over time. Estadı'stica 55, pp. 135-152

5. Brans, J. P., Mareschal, B. (2005). PROMETHEE methods. in Multiple Criteria Decision Analysis: State of the Art Surveys, J. Figueira, S. Greco, M. Ehrgott (eds), Springer Verlag, Boston, Dordrecht, London, pp. 163-196

6. Chang, Y-H., Yeh, C-H., Chang, Y-W. (2013). A new method selection approach for fuzzy group multicriteria decision making, Applied Soft Computing, 13(4), pp. 2179-2187

7. Chen, J., Si, Y., Li, F., Zhao, A. (2014). An analysis of relationship among income inequality, poverty, and income mobility, based on distribution functions. Abstract and Applied Analysis. doi:10.1155/2014/186564

8. Chen, X., Shao, Q., Xu, C-Y., Zhang, J., Zhang, L., Ye, C. (2017). Comparative Study on the Selection Criteria for Fitting Flood Frequency Distribution Models with Emphasis on Upper-Tail Behavior. Water, 9, 320, pp. 1-20

9. Cowell, F. A., Flachaire, E. (2015). Chapter 6 - Statistical Methods for Distributional Analysis. In Handbook of Income Distribution, Atkinson, A.B., Bourguignon, F. (Ed.), Vol. 2, pp. 359465. doi:10.1016/b978-0-444-59428-0.00007-2

10. D'Agostino, R., Stephens, M. (1986). Goodness-of-Fit Techniques. Dekker, 1st edition

11. Delignette-Muller, M.L., Dutang, C. (2015). fitdistrplus: An R Package for Fitting Distributions. Journal of Statistical Software, 64(4), pp. 1-34

12. Hatami-Marbini, A., Kangi, F. (2017). An extension of fuzzy TOPSIS for a group decision making with an application to Tehran stock exchange. Applied Soft Computing, 52, pp. 1084-1097

13. Hsu, L.C. (2014). A hybrid multiple criteria decision-making model for investment decision making. Journal of Business Economics and Management, 15(3), pp. 509-529

14. Ishizaka, A., Nemery, P. (2011). Selecting the best statistical distribution with PROMETHEE and GAIA, Computers \& Industrial Engineering, 61(4), pp. 958-969

15. Kabak, M., Dağdeviren, M. (2014). A hybrid MCDM approach to assess the sustainability of students' preferences for university selection. Technological and Economic Development of Economy, 20(3), pp. 391-418

16. Kassaee, M., Farrokh, M., Nia, H.H. (2013). Integrated Hybrid MCDM Approach for Vendor Selection Problem (Case Study: Iran Khodro). Business and Management Horizons 1(1), pp. 153-170 
17. Kleiber, C., Kotz, S. (2003). Statistical Size Distributions in Economics and Actuarial Sciences, Wiley

18. Kou, G., Lu, Y., Peng, Y., Shi, Y. (2012). Evaluation of classification algorithms using MCDM and rank correlation. International Journal of Information Technology \& Decision Making, 11(1), pp. 197-225

19. Lubrano, M. (2017). The econometrics of inequality and poverty. Chapter 4: Lorenz curves, the Gini coefficient and parametric distributions. pp. 1-43. Available at: http://www. vcharite.univ-mrs.fr/PP/lubrano/cours/Lecture-4.pdf (2.7.2020.)

20. Macharis, C., Brans, J., Marechal, B. (1998). The GDSS PROMETHEE procedure - A PROMETHEE-GAIA based procedure for group decision support. Journal of Decision Systems, 7, pp. 283-307

21. Perić, T., Babić, Z., Šestanović, T. (2019). A hybrid MCDM approach for evaluation of Croatian counties, Lean transformation and digitalization of Serbian industry: proceeding / XII Conference of Business and Science SPIN'19, November 7 - 8, 2019, Belgrade, Serbia. Slović, D., Stojanović, D. (Ed.), pp. 426-432

22. Poklepović, T., Babić, Z. (2014). Stock selection using a hybrid MCDM approach. Croatian Operational Research Review, 5(2), pp. 273-290

23. Saaty, T. L (2001). Decision Making for Leaders. The Analytic Hierarchy Process for Decision in a Complex World. RWS Publications, Pitsburgh USA

24. Salem, A. B. Z., Mount, T. D. (1974). A convenient descriptive model of income distribution: the Gamma density. Econometrica 42, pp. 1115-1127

25. Stephens, M. A. (1974) EDF statistics for goodness of fit and some comparisons. Journal of American Statistical Association, 69, pp. 730-737

26. Stephens, M. A. (1986). Tests based on edf statistics. In Goodness-of-fit techniques, D'Agostino, R.B., Stephens, M. A. (Ed.), Marcel Dekker, New York, pp. 97-194

27. Tao, Y., Wu, X., Zhou, T., Yan, W., Huang, Y., Yu, H., Mondal, B., Yakovenko, V. M. (2019). Exponential Structure of Income Inequality: Evidence from 67 Countries, Journal of Economic Interaction and Coordination, Vol. 14, pp. 345-376

28. Vuković, M., Pivac, S., Babić, Z. (2020). Comparative analysis of stock selection using a hybrid MCDM approach and modern portfolio theory. Croatian Review of Economic, Business and Social Statistics, 6(2), pp. 58-68

29. Wang, Y., Yam, R.C.M., Zuo, M.J. (2004). A multi-criterion evaluation approach to selection of the best statistical distribution, Computers \& Industrial Engineering, 47, pp. 165-180

30. WEF (2017). Section 3: Performance Metrics - National Key Performance Indicators and Inclusive Development Index, World Economic Forum. Available at: http://reports.weforum.org/ inclusive-growth-and-development-report-2017/section-3-performance-metrics-national-key-performance-indicators-and-inclusive-development-index/ (10.9.2020.)

31. WEF (2018). The Inclusive Development Index 2018. Summary and Data Highlights. World Economic Forum. pp. 1-14 


\section{Sažetak \\ ODABIR DISTRIBUCIJE VJEROJATNOSTI KORIŠTENJEM PROMETHEE GDSS METODE}

Rastuće nejednakosti među zemljama su česti predmet istraživanja. Budući da uključuju različite aspekte, u ovom se radu ispituju kroz distribuciju rasta i razvoja zemalja, uključivanja $i$ međugeneracijskog kapitala i održivosti. Ti aspekti uključuju varijable koje nisu normalno distribuirane, pa su predložene, ispitane i uspoređene kroz literaturu različite distribucije vjerojatnosti. Ovaj rad uspoređuje različite distribucije vjerojatnosti koje se smatraju uspješnima u opisivanju distribucije uključenih varijabli, kao što su Weibull, gama, lognormalna, normalna, logistička, Pareto, Burr i eksponencijalna. Uobičajneno se uspoređuju pomoću različitih mjera prilagođavanja koje uključuju funkciju vjerodostojnosti, zbroj kvadrata pogrešaka, zbroj apsolutnih pogrešaka te hikvadrat test, koje ponekad mogu dovesti do različitih zaključaka. Ovaj se rad nadovezuje na prethodno navedene mjere prilagođavanja i uključuje dodatne mjere kao što su Kolmogorov-Smirnov, Cramer-von Mises i Anderson-Darling statistika, srednje apsolutno i kvadratno odstupanje između teorijske i empirijske distribucije vjerojatnosti, srednje apsolutno i kvadratno odstupanje između teorijske i empirijske kumulativne distribucije vjerojatnosti, AIC i BIC informacijske kriterije, kao i odstupanje u asimetriji i zaobljenosti distribucije. Budući da se različite distribucije mogu smatrati alternativama, a mjere prilagođavanja proturječnim kriterijima, problem pronalaska odgovarajuće distribucije vjerojatnosti postaje višekriterijalni problem koji se može riješiti metodom PROMETHEE. Međutim, različiti parametri i funkcije preferencije dovode do različitog rangiranja pa se konačna odluka donosi pomoću PROMETHEE metode za podršku grupnom donošenju odluka (GDSS). Ovaj rad stoga doprinosi postojećoj literaturi o nejednakostima među zemljama i statistici općenito predlažući novi pristup za modeliranje i odabir distribucije vjerojatnosti.

Ključne riječi: distribucija vjerojatnosti, mjere prilagođavanja, PROMETHEE GDSS metoda. 